\title{
Evaluating the Performance of Low-Energy Feed Forward Osmosis System for Desalination using Impaired and Saline Water Sources
}

\author{
Kiran Tota-Maharaj \\ Department of Engineering Science, Faculty of Engineering \& Science, \\ University of Greenwich, Medway Campus, United Kingdom \\ E-mail: k.tota-maharaj@greenwich.ac.uk
}

\begin{abstract}
Forward Osmosis (FO) is a natural process of treating water or wastewater due to the difference in osmotic pressures. FO is a membrane separation technology, applicable to food processing, industrial wastewater treatment and seawater or brackish water desalination. The phenomena of FO processes occur whereby water molecules are driven across a semipermeable membrane by an osmotic pressure gradient that is generated from a higher concentrate draw solution. FO processes can recover potable water resources from wastewater streams through the flow of pure water from a lower concentrated feed solution towards higher concentrated draw solutions leaving behind pollutants, impurities, and salts in the semi-permeable membrane. This paper assesses the design, build and testing of a laboratory scaled Feed Forward Osmosis (FFO) system for treating river water collected from the River Medway, Kent, England. The FO process was a highly effective form of river water treatment and able to treat the River Water with high rejection rates of solutes ( $>90 \%)$. Experimental results showed that the FFO system can achieve a better performance when the molarity of the draw solution is higher. The average solute rejection rate of the FO membrane for both inorganic and organic compounds was $94.83 \%$. Moreover, the operation of the forward osmosis membrane illustrated that it has a lower fouling propensity and higher solute rejection capabilities. The pilot scaled FFO system has the ability for greater salt rejection and lower electronic conductivity levels which resulted from the successful desalination of river water. A sodium chloride $(\mathrm{NaCl})$ or saltwater draw solution performed positively in inducing higher osmotic pressures with a substantial effect of lower energy requirements for the system. Lower energy consumptions of the FFO system allow similar water treatment possibilities with energy savings potential. The FFO system showed to be an environmentally viable and economically feasible river water treatment technology.
\end{abstract}

Keywords: forward osmosis, desalination, river water, draw solution; semi-permeable membrane.

Conference topic: Water engineering (Drinking water quality and treatment).

\section{Introduction}

Fresh potable water resources are an ever-growing demand for the rapid increase in the world's population. Approximately half of the globe's population suffers from water shortages (Guarino 2017) and the number of people affected by water scarcity is expected to increase fourfold within the next 20 years. Over the past few decades, the treatment of water has expanded from various different techniques used to treat all kinds of water sources (surface water, ground water and seawater). In order for countries to keep up with the current demand for clean water, saline water (seawater) and impaired water sources (wastewater) have great potential to meet these current and futuristic requirements. Nevertheless, current resources required to exploit water sources such as seawater and brackish water to create potable water comes at a high costs. As a result of less availability of fresh water resources, membrane separation technologies have made rapid advancements over the years, predominantly due to the stimulus of saline water conversion. This has led to the recent discovery of technologies such as forward osmosis, which creates a new paradigm for desalination and treatment of impaired water sources. The main aim of this project is to study the effects of forward osmosis (FO), on impaired and saline water sources. The objectives of the research project was to conduct research on the effectiveness of FO, to design, build and test a bench-scale Forward Osmosis Cell capable of treating 2 litres of impaired/saline water

\section{Current use of Water Purification and Desalination Technologies}

With rapid development and increase in global population, providing adequate water supply and properly disposing domestic and industrial wastewater is still a problem. From the risk of freshwater shortages, engineers and researchers have been deadling with reclaiming wastewater and finding sustainable alternative water sources (Kucera 2014). Research for treating water and converting it for potable use is still an on-going process. Nowadays, desalination of seawater and brackish water sources as well as water reclamation is becoming more and more attractive to countries for producing high quality water for both industrial, commercial and domestive usage (Achilli et al. 2009; Coday et al. 2014). Reuse of potable and non- potable water sources creates a new set of challenges for engineers, scientist and water utilities and releated industries. Kolpin et al. (2002) found that there is a requirement of advanced technologies

(C) 2017 Kiran Tota-Maharaj. Published by VGTU Press. This is an open-access article distributed under the terms of the Creative Commons Attribution (CC BY-NC 4.0) License, which permits unrestricted use, distribution, and reproduction in any medium, provided the original author and source are credited. 
such as membrane systems to treat and remove micro-pollutants from water sources. Innovation water management practices can have enormous potential for long-term solutions of current water issues. This resulted in the use of different energy efficient technologies that purifies saline and impaired water sources. Various technologies that have been used for water reclamation and desalination include (a) Membrane technologies, (b) Thermal technologies, (c) Concentrate management technologies and (d) Reuse/Recycling Technologies. Among theses technologies, membrane technologies are considered to be the most efficient and effective method for treating the waste water and unconventional water sources.

\section{Forward Osmosis (FO)}

Forward osmosis (FO) is a process which utilises the osmotic pressure, to drive water from contaminated or saline water feed solution across a semi-permeable membrane that retains the dissolves solutes (Miller, Evans 2006; Cath et al. 2006). Figure 1 illustrates the forward osmosis process. Osmosis which is the natural flow of a solvent, generally water across a semi permeable membrane. Forward osmosis is a relatively innovative paradigm within the current membrane processes (Cath et al. 2006). Instead of pumping water through a semi-permeable membrane, FO uses a high concentrate draw solution, which increases the osmotic pressure and draws the water through the membrane; this sequentially reduces the energy required for the treatment process. It may not be the most popular method of treating water, but it is becoming an emerging topic in the water processing industry.

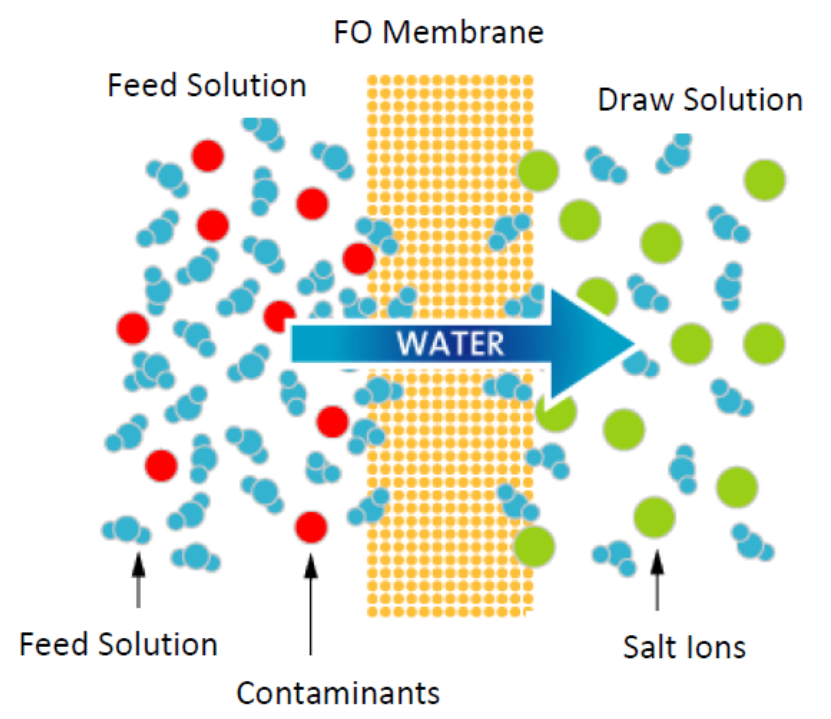

Fig. 1. Forward Osmosis Process (Adapted from Nicoll 2013)

There are several distinctive features of FO desalination and wastewater treatment, when compared to the more conventional methods of reverse osmosis which includes: (i) FO has a lower fouling propensity of the membrane used, this is due to the low pressure required for the process, in which the velocity of the fluids are small, (ii) A so called 'perfect' feed to the more energy intensive reverse osmosis and the double membrane barrier between feed stream and draw stream, (iii) FO has the ability to recycle the additives used in the draw solutions, such as anti-scalants, whilst significantly reducing any contaminants such as Boron that may be otherwise difficult or costly to remove from the product stream and (iv) the energy consumption of FO when compared to conventional methods is substantially lower, in particular where it is deployed on more challenging feedwater, where a conventional RO plant would otherwise operate at lower recovery than the regeneration step (Miller, Evans 2006; Mazlan et al. 2016).

\section{Materials and Methods}

\section{Initial Design Concepts}

After analysing and researching various methods of treating saline and impaired water, a bench scale forward osmosis experiment was designed. The schematic experimental design in figure 2 illustrates the FO treatment system which was used for fabrication and construction purposes. Counter current cross-flow was selected; the feed and draw solution will both run in a simultaneous closed loop system. Feedwater will be circulated from a two litre water tank, through the forward osmosis membrane cell and back to the feed tank using a dual head recirculation pump. Once the FO treatment process is running successfully, the outcomes to be expected is the feed solution becomes more concentrate and on the contrary the draw solution will become more dilute. As a result of this, the system was designed to draw pure water through the membrane, thereby producing an enhanced quality of pure water as an outflow product as discussed by Thompson, Nicoll (2011), Zhao et al. (2012) and Qasim et al. (2015). 


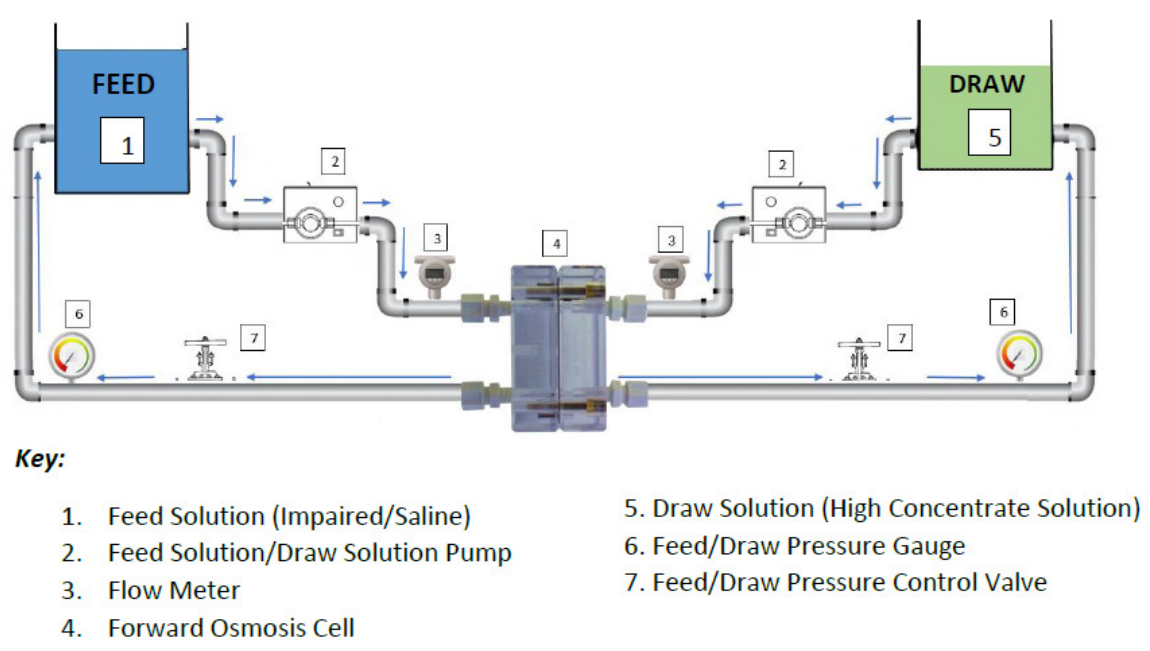

Fig. 2. Schematic design of bench scale FO system (adapted after Thompson, Nicoll (2011), Zhao et al. (2012) and Qasim et al. (2015)

\section{Forward Osmosis Cell Designs}

Figure 2 is a digital sketch of the design concept for the FFO bench scale system. The design is based on a plate system, with a base plate consisting of four $6.4 \mathrm{~mm}$ diameter bolts onto a bottom cell plate and a similar size top cell plate sitting on it. Once the bottom cell plate is in place, the FFO membrane will be placed in the centre of the cell. The top cell plate will be placed on top of the membrane and the bolts used to clamp down the membrane, securing the two cells. The upper and lower cell plates are designed to have inlets and outlets where the feed and draw tubing will be connected. In addition, both cell plates will be drilled through end-to-end for a 4 nut and bolt connector. Oval shape slots are cut out on the top plate. This is done in order for the feed and draw solution to flow through the cell and reach the membrane.

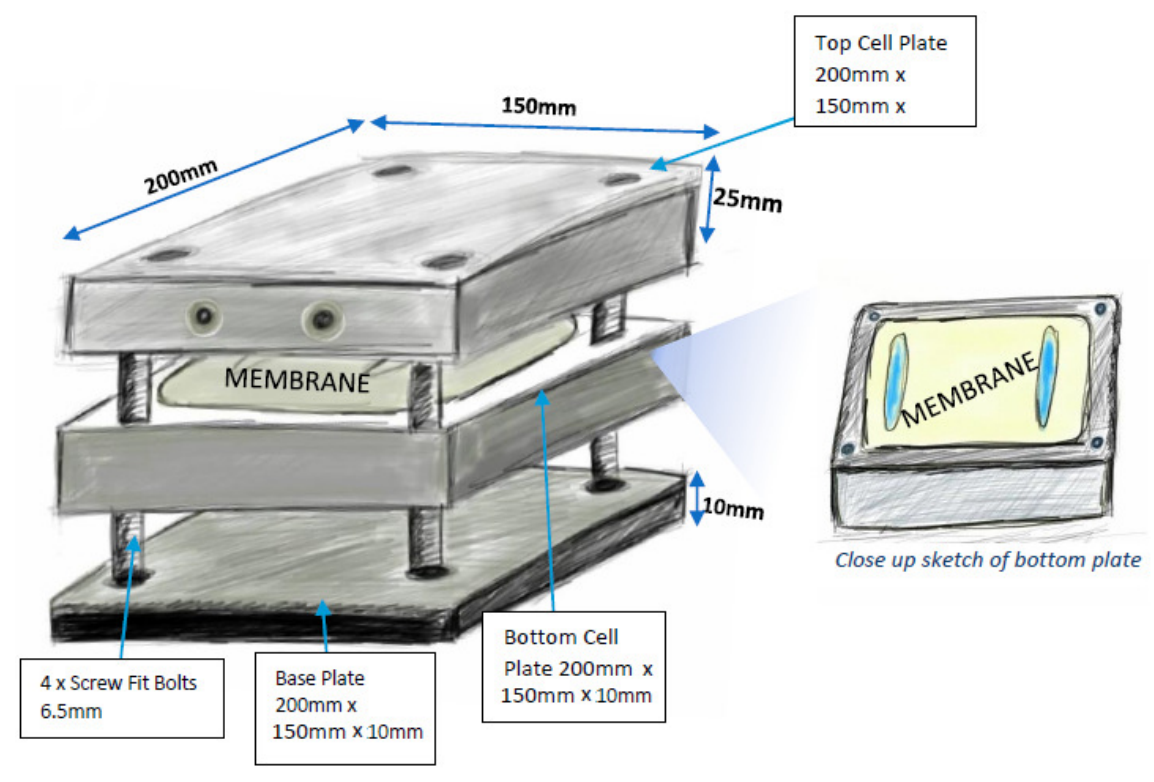

Fig. 2. Forward Osmosis Cell Digital Sketch Design

Figure 3 illustrates the schematic diagram of the laboratory scale FO system where the feed solution and draw solution is passed through a semipermeable forward osmosis membrane. Both the feed solution and the draw solution are recirculated through a close loop system with the use of pump. During the re-circulation, the purewater from the feed solution permeates through the FO membrane towards the draw solution which gets diluted, thereby producing better quality water as an outflow product. 


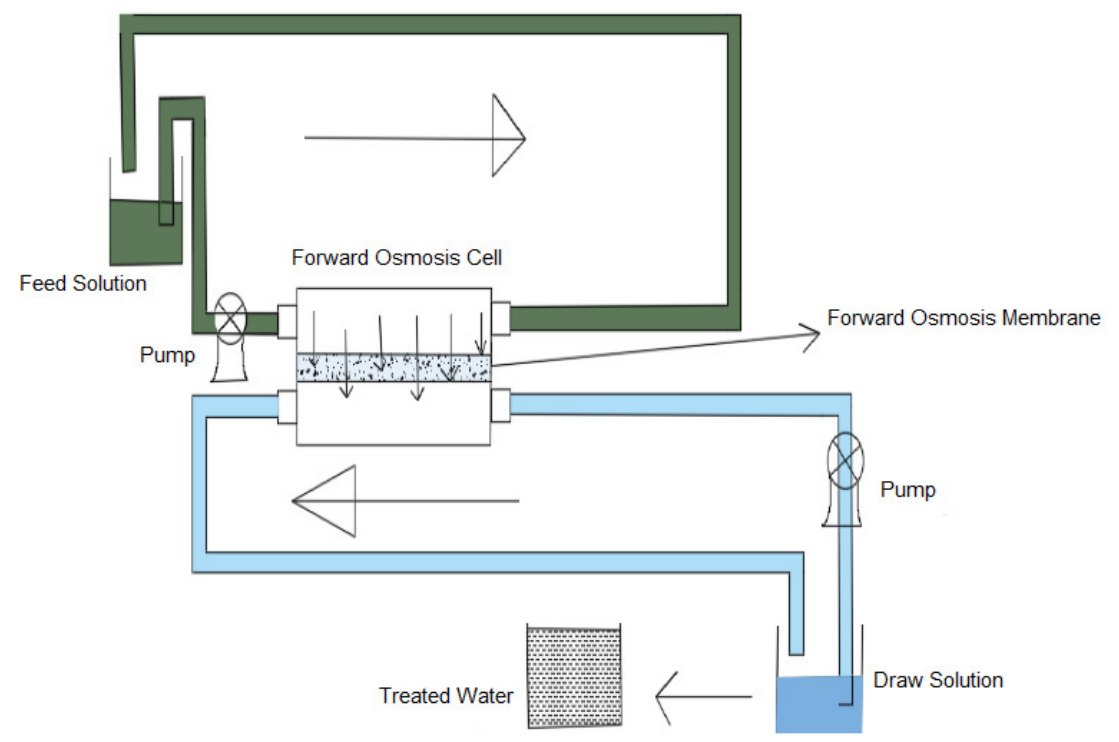

Fig. 3. Schematic layout of bench-scale Forward Osmosis (FO) River water treatment system

\section{Materials Required for Operating Forward Osmosis (FO) Cell}

\section{Pumps, Tubing and Storage}

A Masterflex L/S economy peristaltic pump (London, UK) was selected for the forward osmosis setup. The system did not require high pressure inflows and instead uses the difference is osmotic pressure to draw water through the membrane. The Masterflex L/S specifications included a flow rate range of $56-1700 \mathrm{~mL} /$ minute, electrical frequency of $50-60 \mathrm{~Hz}, 0.8$ Ampere and 230 volts. Two water containers were required, to store and convey the feed and draw solutions. The project is designed to treat 2 litres of water, therefore 2.5 litre containers were chosen. A Masterflex (London, UK) L/S pump tubing is manufactured to extremely close tolerances that match the Masterflex, $\mathrm{L} / \mathrm{S}$ pump heads, ensuring accurate, repeatable flow and long tubing life. The pump tubing is factory-tested and optically inspected to provide the best performance from the peristaltic pump. The tubing is chemically inert; offering the best chemical resistance of any pump tubing and has a rigid tubing structure that provides strength and durability.

\section{Forward Osmosis Membrane}

Aquaporin FO flat sheet membranes (Kongens Lyngb, Denmark) were used for the separation process that required low energy and low flow pressures. The Aquaporin FO membranes are still in the development stage and are relatively fragile. The use of a spacer on the active side of the membrane was avoided as it can damage the Aquaporin Inside coatings affecting the desalination process. The system was setup to run at low cross flow velocities and slow flowaters to keep the shearstress at a minimal at the membrane surface. If high cross flow velocities/flowrates are not required for fouling control, flowrates were lowered as much as possible. The project encorporated a peristaltic pump which provided ideal conditions of low flowrates (Fig. 4).

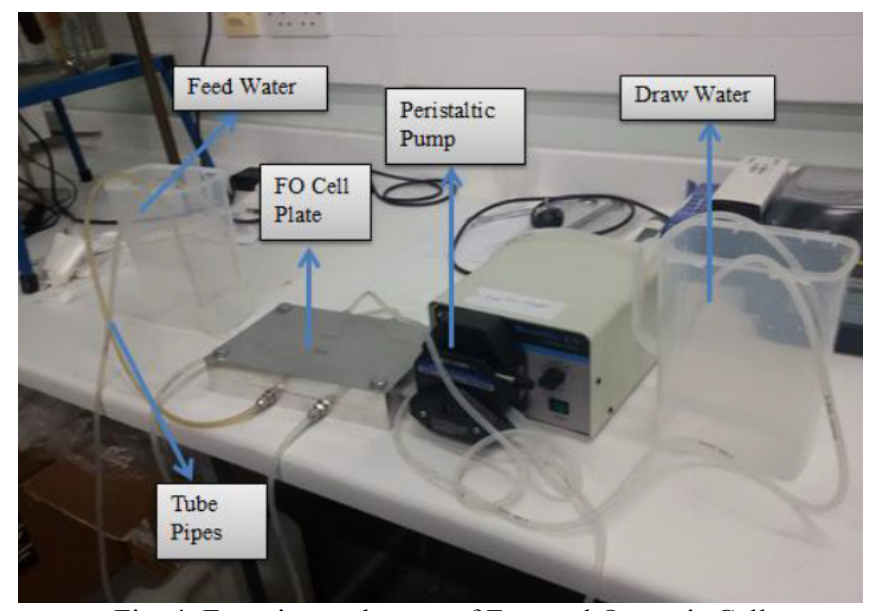

Fig. 4. Experimental setup of Forward Osmosis Cell 


\section{Experimental Procedures of Forward Osmosis Cell}

The following steps give the experimental procedure and operation of the Forward Osmosis Cell:

Step 1 (Preparation of the Feed Solution) - River water was collected twice weekly from the Medway River, Kent, England, UK. The river was then filtered through (filter paper) as a pre-treatment stage to prior to the forward osmosis stage.

Step 2 (Preparation of the Draw Solution) - Draw solutes such as salt $(\mathrm{NaCl})$ and Sugar or sucrose $\left(\mathrm{C}_{12} \mathrm{H}_{22} \mathrm{O}_{11}\right)$ were used in the laboratory to prepare the draw solution. Distilled water was placed in a tank whereby the draw solutes were poured in. Here, the Molar mass of $\mathrm{NaCl}$ is $58.44 \mathrm{~g} / \mathrm{mol}$, meaning $1 \mathrm{M}$ of $\mathrm{NaCl}$ draw solution requires 58.44 grams of $\mathrm{NaCl}$ solute per litre of sample. Similaraly, the molar mass of sucrose/sugar $\left(\mathrm{C}_{12} \mathrm{H}_{22} \mathrm{O}_{11}\right)$ is $342.29 \mathrm{~g} / \mathrm{mol}$, meaning for $1 \mathrm{M}$ of sucrose/sugar drawn solution requires 342.29 grams of sucrose solutes per litre of sample.

Step 3 (Assembling of the Forward Osmosis rig) - The base and top plates are clamped together with the aid of nuts and bolts, with O-rings and the Aquaporin FO flat sheet membrane placed between them.

Step 4 (Attaching tubing to inlet and outlet fittings) - Altogether, there are four number of tube pipes which are attached to the inlet and outlet fittings of the FO cell plate.

Step 5 (Connection the tube pipes with pumps and Feed/Draw solution) - The tube pipes for both feed and draw solutions are connected with the peristaltic pump, where the draw solution flows in the opposite direction with regards to the feed solution.

\section{Water Quality Testing and Analysis}

The water quality parameter tests involved testing the inflow water samples collected from Medway River, UK and the outflow produced by the FO experimental set-up. Each parameter being tested, involves different testing procedures and testing apparatus, the following text is a breakdown of each of the testing procedures:

- Filtration (Pre-Treatment) - Filter paper of size $150 \mathrm{~mm}$ are used to filter the river water. These filter papers are placed in to a funnel. After that, the collected water sample is passed through a filter paper which helps to remove the impurities and suspended particles from the water sample.

$-\mathrm{pH}$ and Temperature - The water and feed fluid $\mathrm{pH}$ and temperature testing was carried by using a Hanna HI-8314 pH and temperature meter(Bedfordshire, UK). The meter was calibrated before use and dipped in to the sample in order to obtain the result of $\mathrm{pH}$ and temperature $\left({ }^{\circ} \mathrm{C}\right)$

- Colour - The colour of water samples was measured using a Hanna HI-727 colour checker (Bedfordshire, UK). The colour meter uses the Colorimetric Platinum Cobalt method (an adaptation of the Standard Methods for the Examination of Water and Wastewater, 21 th edition).

- Turbidity - The turbidity of the water samples were checked using a microprocessor based turbidity meter (Hanna HI-93703 portable turbidity meter) that conveys, laboratory grade accuracy. The meter was also obtained from the same manufacture Hanna Instruments (Bedfordshire, UK). The meter has a sensor that picks up how much light has passed through the water test sample and how much has been scatted by the suspended particles. The readings are then displayed in FTU value (Formazin Nephelometric Units).

- Ammonium, Nitrite, Nitrate, Phosphate and Chemical Oxygen Demand (COD) - The DR1900 portable HACH (Salford, UK) Spectrophotometer was used to test for Ammonium, Nitrite, Nitrate, Phosphate and COD concentrations. The tests were conducted by adding droplets of each sample into the LCK chemical cuvettes that were also obtained from HACH. COD and phosphate testing required heating of the mixed cuvette sample using a HACH Lange Thermostat (Salford, UK), prior to testing using the spectrophotometer (Hach Lange 2015).

- Electronic Conductivity (EC) and Total Dissolved Solids (TDS) - The EC and TDS were measured using a HM Digital (UK), hand held EC/TDS/Temperature meter. The parameter and unit of measure was selected followed by calibration using deionized water. Once the device was calibrated it was dipped into the sample, press read and the value for EC/TDS was revealed on the digital display.

- Biochemical oxygen demand (BOD) -The BOD 5 was measured by use of an Oxi-Direct Lovibond BOD meter (Nottingham, UK). The Lovibond sensor system allows precise measurements of BOD based on the manometric principle.

\section{Results and Discussion \\ Comapring $\mathrm{NaCl}$ and Sucrose (Sugar) as Draw Solutes}

The feed solution was collected from Medway River, and the draw solution was varied ( $\mathrm{NaCl}$ or Sucrose). At first, 1 molar of $\mathrm{NaCl}$ was used as a draw solute and the river water was treated through the FO cell. The time taken to treat the whole feed water was measured. Thereafter, 1 molar of Sugar (Sucrose) was used as draw solute for the treatment 
and time taken measured. Moreover, the concentration of solutes was increased from 1 molar to 2 molar and comparison made for better understanding of draw solutes (Fig. 5) From Fig. 5, it can be seen that by using the draw solute as $\mathrm{NaCl}$, the time taken to treat the feed water is faster than that of the sugar (sucrose) solute. For the 1 molarity concentration of $\mathrm{NaCl}$, the time taken to treat the feed water was 125 second whereas for the $1 \mathrm{M}$ concentration of sugar, the time taken to treat the same feed water was $165 \mathrm{sec}$. As the concentration of molarity increases, the time taken to complete the treatment of feed water decreases. This means by increasing the concentration of molarity treats the feed water faster. This is the reason why $\mathrm{NaCl}$ is more popular draw solutes than that of sugar for the $\mathrm{FO}$ process.

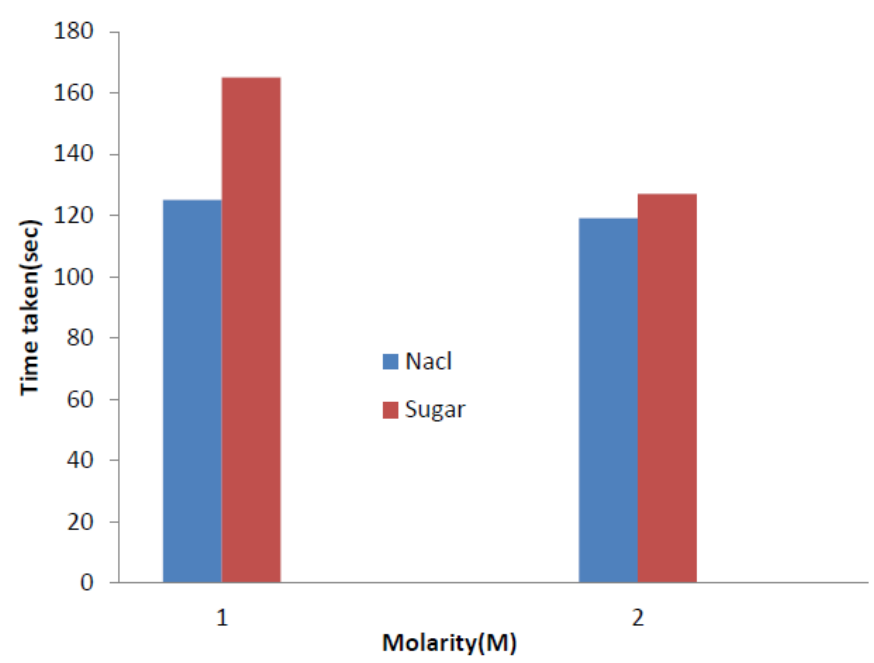

Fig. 5. $\mathrm{NaCl}$ and Sugar with time taken vs. Molarity (M)

The outflow results from the FO desalination system was compared to the UK's Drinking Water Inspectorate DWI (2015) water quality standards and comparisions were made to ensure that all parameters are within the recommended guidelines for potable water consumption. Figure 6 presents the set of results from January-May 2016 with a sample number of 40. It can be seen (Figure 6) thath the forward osmosis was very effective form of water treatment, having significantly reduced all parameters which were tested. These include $\mathrm{pH}$ (The levels of each test conducted during the first phase of testing remained neutral within the range of 7-8.5 which concurs with the DWI (2015) standards. Colour, a key aesthetic measure of the quality of drinking water is vital to ensure that the outflow water from the FO system is well within the recommended guidelines. The colour of water obtained from Medway river was relatively clear with few visible suspended particles. The outflow results revealed that the colour present in each sample was reduced to the recommended DWI (2015) standards.

Turbidity which measures the suspended particulate matter in water has a direct correlation with varying levels of pollution. The turbidity levels of the samples tested were relatively low, which reveals that the total suspended solids of the water were considerably low. The outflow concentrations of turbidity were also within the recommended guidelines of DWI (2015). The reduction of ammonium in all tests was very consistent producing close to zero (mg/l), all within the DWI (2015) standards of less than $1.5 \mathrm{mg} / \mathrm{l}$. Ammonium nitrogen, ammonium, ammonia and ammonia nitrogen were relatively low in concentrations from the feed sample (Medway river) $<2.5 \mathrm{mg} / \mathrm{l}$. Nevertheless, these concentrations were further reduced to $0.01 \mathrm{mg} / \mathrm{l}$ and zero for several readings. The nitrite concentrations for all the river water samples were recorded as $0 \mathrm{mg} / \mathrm{l}$, hence it was difficult to judge the FO treatment capabilities of nitrite content. Although it is common that nitrite levels are low in unpolluted waters as mentioned by World Health Organization (2011). In general the nitrate concentrations of river water sources are relatively low as revealed by the inflow results obtained from the test. Although an increase in nitrate levels is possible in sources of water, that have had manmade interruptions such as fertilizer runoff, septic systems and improperly treated wastewater.

The chemical oxygen demand (COD) removal rates show the amount of organic compounds and pollutants retained by the FO membrane process. Mean inflow COD concentrations were $55 \mathrm{mg} / 1$ with an average effluent leaving the system at $0.056 \mathrm{mg} / \mathrm{l}$. Close to $100 \%$ reduction of COD occurred throughout the experiments, indicating there was no further treatment required for COD. Assessment of COD is a key way to ensure that there is no organic matter remaining in the effluent water produced by the treatment of FO. Biochemical oxygen demand or biological oxygen demand (BOD) is the oxygen required by aerobic biological organisims to break down organic matter. BOD gauges the effectiveness of the FO water treatment process. The mean inflow BOD concentrations were $2 \mathrm{mg} / \mathrm{l}$ and the average outflow was $0.5 \mathrm{mg} / \mathrm{l}$. 


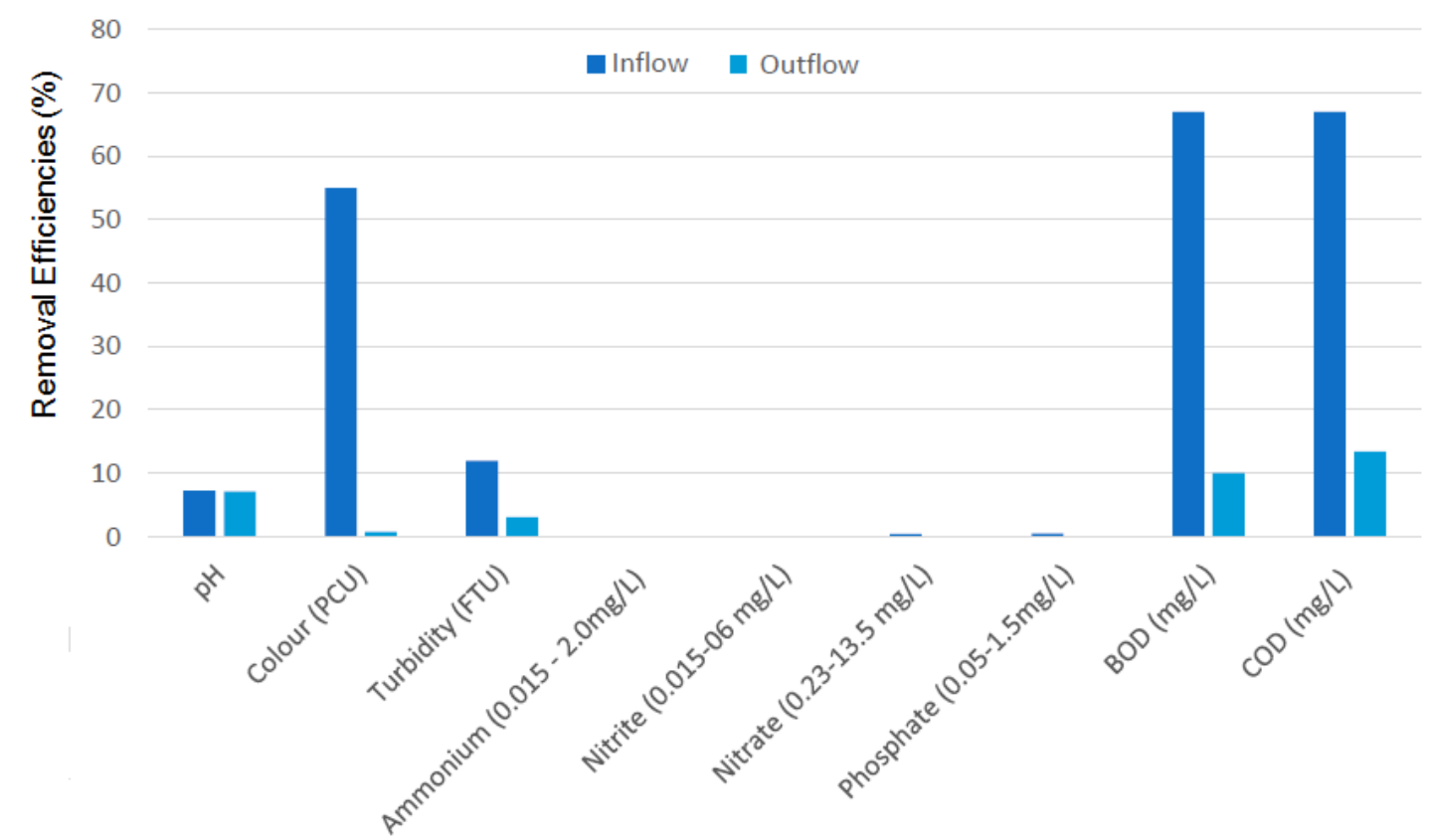

Fig. 6. Average Influet versuse Outflow for Forward Osmosis system (sample number n = 40, January-May, 2016)

Table 1. Rejection rate obtained after treatment of Medway River water by FO membrane conducted in laboratory for various water parameters (January-September, 2016)

\begin{tabular}{|c|c|}
\hline Water parameters & Rejection Rate (\%) \\
\hline $\mathrm{pH}$ & 2.8 \\
\hline Turbidity (FTU) & 84.3 \\
\hline Colour (PCU) & 96.7 \\
\hline $\mathrm{NH}^{4+}-\mathrm{N}(\mathrm{mg} / \mathrm{l})$ & 84.4 \\
\hline $\mathrm{NH}^{3}(\mathrm{mg} / \mathrm{l})$ & 89.4 \\
\hline $\mathrm{PO}^{3-}-\mathrm{P}(\mathrm{mg} / \mathrm{l})$ & 99.7 \\
\hline $\mathrm{PO}_{4}{ }^{3-}(\mathrm{mg} / \mathrm{l})$ & 98.0 \\
\hline $\mathrm{BOD}$ at 5 days $(\mathrm{mg} / \mathrm{l})$ & 75.7 \\
\hline $\mathrm{COD}(\mathrm{mg} / \mathrm{l})$ & 99.9 \\
\hline Nitrite $(\mathrm{mg} / \mathrm{l})$ & 97.6 \\
\hline Nitrate $(\mathrm{mg} / \mathrm{l})$ & 99.7 \\
\hline Electronic conductivity $(\mathrm{EC}) \mu \mathrm{S} / \mathrm{cm}$ & 99.2 \\
\hline Total dissolved solids (TDS) $(\mathrm{mg} / \mathrm{l})$ & 98.8 \\
\hline
\end{tabular}

Table 1 demonstrates for the designed bench-scale laboratory FO cell system was successful in treating the Medway River water with very high rejection rates of the physio-chemical water paraters $(>84 \%)$. The $\mathrm{BOD}_{5}$ rejevtion rates were in the mid-70 range as a result of the low inflow concentrations (BOD $<5 \mathrm{mg} / \mathrm{l})$. Higher rejection rate for all other water parameters was noted.

\section{Conclusions and Outlook}

Forward osmosis is currently a dynamic field in the water processing industry that is undergoing a number of stresses that could ultimately see its decease, major breakthrough or somewhere in between. Despite the lack of robust membranes and membrane modules for FO, basic research on FO and the development of new applications of FO are steadily growing. Currently, the most important measure to be taken in order to advance the field of FO is the development of new membranes in both flat-sheet and hollow fibre configurations. In addition development of draw solutions that can induce high osmotic pressure is another important step towards further progress of the FO process. Most 
desirable are draw solutions that require low energy for regeneration or reconcentration, that are easily separable from the product water, that have low or no toxicity, and that are chemically nonreactive with polymeric membranes. With increasing demands of water and drinking water resouces, reclamation water, seawater and brackish water treatment can be a feasible option in meeting these needs. The FO cell was a highly effective form of water treatment. Experimental results showed that the FO can achieve a better performance when the molarity of the draw solution is higher for $\mathrm{NaCL}$ and sucrose. Moreover, the operation of the FO membrane shows that it has lower fouling propensity and higher solute rejection capabilities. During the experiment, the average solute rejection capability of the FO membrane on both inorganic and organic compounds was $94.83 \%$. The FO system has the ability of greater salt rejection rates and lower electronic conductivity levels which results for successful desalination of water. Investment in the large scale industry like desalination plants will be beneficial in the long-term. Furthermore, $\mathrm{NaCl}$ as a draw solution that the capabilities to induce high osmotic pressures which would consume less energy for operation. The lower energy consumption characteristics of FO systems can therefore treat water and wastewater with lower energy cost. From the operations of the FO system, the movement of water from the feed solution towards the draw solution through the FO membrane by the high osmotic pressure developed and rejection of the impurities in the membrane allowed the clearer cleaner water as an output. The system showed a good performance can become even more environmentally friendly and be an economically viable water treatment option.

\section{Acknowledgements}

The author would like to thank Thanusanth Jasan (Civil Engineering Undergraduate Student) and Shakti Baniya (Civil Engineering Postgraduate Student) at the University of Greenwich who contributed to this experimental project. The author also gratefully acknowledges the technical staff (Mr. Ian Cakebread) and technicians (Mr.Tony Stevens and Mr. Colin Gordon) from the Department of Engineering Science at the University of Greenwich.

\section{Funding}

University of Greenwich, Faculty of Engineering and Science, Research Excellence Framework (REF) Internal Grant for Wastewater Engineering and Water Reuse Projects Funding.

\section{Contribution}

Dr. Kiran Tota-Maharaj (University of Greenwich) developed the conception and design of the project and also drafted the research article. Mr. Thanusanth Jasan (Civil Engineering Undergraduate Student) and Mr. Shakti Baniya (Civil Engineering Postgraduate Student) University of Greenwich acquired datasets, conducted research experimetns on the project and also analysed data outputs for this research project.

\section{Disclosure statement}

The author (Dr. Kiran Tota-Maharaj) certify that he has No Affliations with or in-volvement in any organisation or entity with competing financial interest, professional or non-financial interest in the subject matter and materials discussed in this manuscript.

\section{References}

Achilli, A.; Cath, T. Y.; Marchand, E. A.; Childress, A. E. 2009. The forward osmosis membrane bioreactor: a low fouling alternative to MBR processes, Desalination 239(1-3): 10-21. https://doi.org/10.1016/j.desal.2008.02.022

Cath, T. Y.; Childress, A. E.; Elimelech, M. 2006. Forward osmosis: principles, applications, and recent developments, Journal of membrane science 281(1): 70-87. https://doi.org/10.1016/j.memsci.2006.05.048

Coday, B. D.; Xu, P.; Beaudry, E. G.; Herron, J.; Lampi, K.; Hancock, N. T., Cath, T. Y. 2014. The sweet spot of forward osmosis: treatment of produced water, drilling wastewater, and other complex and difficult liquid streams, Desalination 333(1): 23-35. https://doi.org/10.1016/j.desal.2013.11.014

Drinking Water Inspectorate (DWI). 2015. Guidelines of drinking water quality. London, UK.

Guarino, A. S. 2017. The economic implications of global water scarcity, Research in Economics and Management 2(1): 51. https://doi.org/10.22158/rem.v2n1p51

Hach Lange. 2015. Labratory analysis Lange Cuvette test. London: HACH.

Kolpin, D. W.; Furlong, E. T.; Meyer, M. T.; Thurman, E. M.; Zaugg, S. D.; Barber, L. B.; Buxton, H. T. 2002. Pharmaceuticals, hormones, and other organic wastewater contaminants in US streams, 1999-2000: a national reconnaissance, Environmental science and technology 36(6): 1202-1211. https://doi.org/10.1021/es011055j

Kucera, J. (Ed.). 2014. Desalination: water from water. John Wiley \& Sons, New Jersey, USA.

Mazlan, N. M.; Peshev, D.; Livingston, A. G. 2016. Energy consumption for desalination - a comparison of forward osmosis with reverse osmosis, and the potential for perfect membranes, Desalination 377: 138-151. https://doi.org/10.1016/j.desal.2015.08.011 
Miller, J. E.; Evans, L. R. 2006. Forward osmosis: a new approach to water purification and desalination. United States Department of Energy, Sandia National Laboratories, 1-52. https://doi.org/10.2172/893156

Nicoll, P. G. 2013. Forward osmosis - a brief introduction, in Proceedings of the The International Desalination Association World Congress on Desalination and Water Reuse, 20-25 October 2013, Tianjin, China.

Qasim, M.; Darwish, N. A.; Sarp, S.; Hilal, N. 2015. Water desalination by forward (direct) osmosis phenomenon: a comprehensive review, Desalination 374: 47-69. https://doi.org/10.1016/j.desal.2015.07.016

Thompson, N. A.; Nicoll, P. G. 2011. Forward osmosis desalination: a commercial reality, in IDA World Congress-Perth Convention and Exhibition Centre (PCEC), Perth, Western Australia September, 4-9.

Zhao, S.; Zou, L.; Tang, C. Y.; Mulcahy, D. 2012. Recent developments in forward osmosis: opportunities and challenges, Journal of Membrane Science 396: 1-21. https://doi.org/10.1016/j.memsci.2011.12.023

World Health Organization. 2011. Nitrate and nitrite in drinking-water Background document for development of WHO Guidelines for Drinking-water Quality [online], [cited 04 February 2017]. Available from Internet: http://www.who.int/water_sanitation_health/dwq/chemicals/nitratenitrite2ndadd.pdf 